\title{
Performance Assessment of Industrial Real Estate Contribution to Nigerian Economy
}

\author{
Nurudeen Akinsola Bello ${ }^{1}$, Ismail Kolawole Bello², Olufola Toyosi Elegbede ${ }^{3}$ \\ ${ }^{1}$ Department of Estate Management, Faculty of Environmental Sciences, University of Ilorin, Kwara State, Nigeria \\ ${ }^{2}$ Department of Estate Management, School of Environmental Studies, Moshood Abiola Polytechnic, Abeokuta, Ogun State, Nigeria \\ ${ }^{3}$ Department of Estate Management, Faculty of Environmental Studies, The Polytechnic, Ibadan Oyo State, Nigeria \\ Email address: \\ bello4all007@yahoo.com (N. A. Bello), ismailbello@yahoo.com (I. K. Bello), foldot@yahoo.com (O. T. Elegbede)
}

\section{To cite this article:}

Nurudeen Akinsola Bello, Ismail Kolawole Bello, Olufola Toyosi Elegbede. Performance Assessment of Industrial Real Estate Contribution to Nigerian Economy. Journal of Investment and Management. Vol. 4, No. 5, 2015, pp. 132-140. doi: 10.11648/j.jim.20150405.11

\begin{abstract}
This work is set to measure the contribution of real estate to the production output of manufacturing industries in Nigeria and relate it to the gross domestic product of Nigeria with a view to providing guidance for the industrial investors, measuring past achievements and providing the basis for planning and control decisions. 44 of the 108 industries in industrial town of Ota in Nigeria were randomly sampled to elicit data between 2008 and 2012 from heads of administration of each industry and data collected were analyzed using descriptive statistics. The findings indicated that at aggregate level, industrial properties in Ota, Nigeria contributed 19\% performance to the manufacturing success of industrial establishments. Furthermore, while both contributions of manufacturing sector to the national economy and the industrial real estate to manufacturing output are not steady or specific in trend, the average of the contribution of manufacturing/industrial sector to Nigerian economy from 2008-2012 as gathered from various sources indicated 3.41\%, the implication of this is that the industrial real estate's actual contribution to Nigerian economy is $0.65 \%$. This work did not measure the value (capital or rental) to determine performance of industrial properties; rather it rated the performance of each standard economic factors of production (land, labour, capital and entrepreneur) base on their contribution to the production activities of the industries by conversion of qualitative perception of the respondents to quantitative measurement. Further endeavor is desired to have pure quantitative measurement as improvement on this qualitative perception. The field of real estate of manufacturing industry lacks empirical measurement to quantify the value that it adds to the firm's performance and this has made the contribution of real estate to the firm not properly considered or recognized. This work is therefore non-economic parameter used to quantify the contribution. The benchmarks developed in this work were found to be measurable and appropriate for owner occupied industrial buildings and makes collection of data simple. The work advanced the benchmarks required for the performance evaluation of industrial buildings without resorting to determination of actual value. This will be useful for government to fix industrial real estate in the national economic importance as against the usual real estate investment contribution to the national economy.
\end{abstract}

Keywords: Industrial Real Estate, Industrial Sector, Performance, Production Output, National Economy, Gross Domestic Product

\section{Introduction/Background to the Study}

Land and real estate proved not only to be central to man need and activities but also as the most crucial factor of production. In view of today's globally difficult economic situations, more and more groups of companies realize that their real estate property does not belong among the core business anymore.

The value of industrial real estate is primarily examined in relation to local economic conditions, property location and physical characteristics. The objectives of having industrial property according to [1] include; fulfilling workplace need of business growth, meeting the individual need of business operating divisions and maximizing the investment and capital value of portfolio. The management of industrial property may be in-house affair or hands-off affair depending on the policy of the industrial establishment. Industrial property has always been the poor relation in any sectoral assessment of real estate markets [1].

These assets in most cases have therefore been assessed on the ability of the occupier to pay for the space, resulting in an 
expression of the financial return from the investment. This concept is being expanded today by astute investors who are taking account of longer-term considerations, and, in particular, the sustained optimal utility of the space.

Maximizing the contribution of property to the wealth maximization of the firm's shareholders will require development of an organizational strategic plan that drives a supporting real estate strategy. Successful implementation of the selected real estate strategies will require the development of a comprehensive performance management system to provide a feedback loop to assess progress and make adjustments as needed.

The Real Estate Sector's contribution to Gross Domestic Product (GDP) of Nigeria has been previously established at $7 \%$ region between 2010 and 2012 as it went from $7.56 \%$ in 2010 , down by $0.28 \%$ points in 2011 and showing a slight increase in 2012 up to $7.73 \%$ [2], none of such was noted as regards the contribution of the industrial real estate, this work is an attempt to measure the performance of property held for industrial usage but not industrial investment or investment in industrial property.

In measuring performance of industrial investment generally, economic and non-economic parameters may therefore be used. Property performance evaluation has traditionally been accepted as referring to the performance of an investment asset, this is different from performance as a corporate asset (where property is used as operational asset).

This is basically to measure the contribution of industrial property as a factor or contributor to the overall industrial investment performance and at ultimate end determines its actual contribution to the gross national product of Nigeria.

To achieve this aim, the reminder of the paper has been structured into 7 sections. The next section states the research problem. The third section is on conceptual framework, the fourth section review the related literature, followed by study area and methodology in the fifth section. The sixth section is on the findings and discussion of the findings before the work is eventually concluded.

\section{The Research Problem}

Corporate occupiers have begun to understand the importance of real estate to the business function-to know if they are reaping the benefit or not. The data for evaluation performance include estimated rental value, rent passing, capital value, physical characteristics, management costs, tenure and yield which in most cases may not be easily gotten because of absence of a decent time-series of market data in most industrial markets across the channel caution of taxation taken by most establishments.

The question to answer while evaluating the performance of industrial property includes; is the property use to maximize revenue- investment return or business profit?, are their identifiable ways of improving the performance of the property? and is the property appropriate within the overall portfolio? Performance measurement can be made even more effective if there is opportunity to compare the performance of the organization's real estate as a cost base and as an operating base with other occupiers in similar business. As businesses strive to improve their competitive position in an ever more crowded marketplace, strategic use of all their resources, including real estate is necessary to succeed.

The number of studies devoted to examining the performance of commercial or industrial real estate as an investment category is very small compared with studies for other asset markets, and yet real estate represents an important component of invested funds [3]. The roles of property in business transaction are in asset base, cost base and trading base [1]. Performance measurement studies on investment in Nigeria show that performance indicators used are based on ease of measurement or access to information [4].

The basic principles of a successful real estate policy are a customer-oriented organizational structure as well as the creation of efficient business processes. The classification of real estate will have a stronger focus on the features of efficiency and usability than in the past where the emphasis was rather on operational necessities. Whereas in the real sense of it, current situation of companies requires a groupwide adoption of responsibility for the real estate management and the actual contribution of each of the partakers in the production process.

Measuring performance has an important role in measuring past achievements and providing the basis for planning and control decisions. Measurement of service delivery/performance is aimed at establishing the satisfaction of clients or users of a product and services. This is done by comparing the actual perception of the service/product against the expectation of the users. The degree of discrepancy between consumer's perceptions and expectations dictates the service quality and level of satisfaction of consumers/users of the products/services.

In the view of [5] performance of real estate depends on a number of factors and statistical analysis provides a useful tool in analyzing the importance of industrial property characteristics in performance.

The field of real estate of manufacturing industry lacks empirical measurement to quantify the value that it adds to the firm's performance. This indicate that the contribution of real estate to the firm and the possibilities that exist for adding value are often not recognized nor properly considered. Realization that both tangible and intangible assets are important to the successful support of the core business calls for a broader view of real estate's contribution to the firm and ultimately to the overall national economy.

Current methods of investment performance measurement have been derived from stock market and fixed interest data and the theory of investment performance measurement of fixed interest and stock market investments has been addressed in detail in recent years, but very little attention has been paid to the measure of performance of property investments in the works of $[6,7,8,9,10,11,12,13,14,15,16]$ etc.

These methods cannot be applied to property performance 
measurement without substantial adjustment because of its different characteristics, in particular the difficulties of placing a value on properties, their indivisibility and duration of the property cycle[17]

The contribution of industrial/manufacturing sector to the national economy has been previously done using performance indicators such as index of manufacturing production, manufacturing capacity, inflation rate and sector growth rate, and these has indicated that the contribution of manufacturing sector to the gross domestic product of developing country like Malaysia is $45 \%$ (more than the one obtained from developed nations 35\%-45\%).

[18] has however put the contribution of industrial/manufacturing sector to the gross domestic product of Nigeria as less than $5 \%$ and this was also corroborated by Manufacturing Association of Nigeria (MAN) as it also documented that the average contribution of industrial/manufacturing from period of 2007-2013 is less than $5 \%$, but no noted work has actually documented the contribution of industrial property to the gross domestic product of Nigeria.

In addition, while a lot have been written on property performance generally and industrial property performance of investment asset specifically, little was actually written on industrial property performance of operational asset and this is a noted gap in literature that this work is set to fill. This work is therefore set to measure the contribution of real estate to the production output of manufacturing industries in Ota, Ogun State, Nigeria and relate it to the gross domestic product of Nigeria with a view to providing guidance for the industrial investors, measuring past achievements and providing the basis for planning and control decisions.

\section{Conceptual Framework}

Production is the basic process of transforming naturally occurring materials that provide little satisfaction in their natural state to goods and services that provide more satisfaction. Generally, the production of any good or service inevitably requires four types of inputs; Labor, capital, land, and entrepreneurship used by society to produce consumer satisfying goods and services. Economists have used these four general categories since the days of Adam Smith and the lines between these four resource categories are frequently blurred in the modern complex economy and society.

Labor is the mental and physical efforts of humans excluding entrepreneurial organization used for the production of goods and services. Entrepreneurship is the special sort of human effort that takes on the risk of bringing labor, capital, and land together to produce goods. Capital is the manufactured, artificial, or synthetic goods used in the production of other goods, including machinery, equipment, tools and vehicles while Land is the naturally and artificial occurring materials of the planet that are used for the production of goods and services, including the land itself and buildings build on it to accommodate production processes.
Industry can be said to be "a particular way of organizing production and assumes there is a constant process of technical and social change which continually increases society's capacity to produce a wide range of goods" [19]. The manufacturing sector is particularly important in the process of industrialization because of its multi-dimensional benefits to the development process. Indeed, some authors define industrialization in terms of increase in the share of the gross domestic product contributed by the manufacturing sector [20].

According to [21], the manufacturing sector of any economy worldwide is reputed to be the engine of growth and a catalyst for sustainable transformation and national development. This is because of its enormous potentials as a tool for creating wealth, generating employment, contributing to the country's Gross Domestic Product as well as alleviating poverty among the citizenry, hence, [22] described industry and in particular the manufacturing subsector, as the heart of the economy, but there cannot be manufacturing activities without the industrial properties in form of land and real asset.

Industrial properties are land, structural improvement and equipment connected with a particular property which is being used for the conversion of materials into finished manufactured produces. It is expected that industrial property is highly correlated with property characteristics.

In developing its Competitive Industrial Development Index, the United Nations Industrial Development Organization (UNIDO) defined the components of the index in terms of the attributes of a country's manufacturing sector [23]. Accordingly, industrial development report identified Manufacturing Value Added (MVA) as one of the measurement of industrial performance in which industrial properties are prominent.

Most of industrial real estate are used as whole usage rather than share usage, for instance, in US one half of industrial space is owner occupied and majority of rental structures have a single tenant, therefore most industrial property are built by or for its occupancy directly making the issue of rent passing difficult to come by in industrial performance measurement [24] and collection of industrial property data hamper by market data problem, this is also noted in Nigeria.

In the view of [5] performance of real estate depends on a number of factors and statistical analysis provides a useful tool in analyzing the importance of industrial property characteristics in performance. The metrics used to determine the contribution of real estate are primarily focused on cost reduction or capital minimization. What is often not recognized is that property can also help to improve revenues. Both avoiding costs and enabling others in the organization to improve their services and consequently increasing revenues contributes to profitability and add value to the firm.

One way of looking at how real estate can add value to the firm is using the framework shown in [25] Balanced Scorecard (BSC). In their model, organizations can increase economic value through revenue growth and/or productivity. 
Revenue growth comes from new markets, new products, new customers, and expand sales to existing customers. Productivity results from reducing expenses and using assets more efficiently.[26] translates the BSC view to show how corporate real estate can add value through growth and profitability.

From an organization and management perspectives, performance is measured by the realization of the organization's goals. From performance measurement perspective, performance is seen as an object's ability to achieve desired results but from corporate real estate management point of view, performance can be seen as the ability of the real estate to support the organizational objectives, strategies and at the end, business success [27] Applying the disciplines of performance evaluation helps property managers and operators to determine important issues that are crucial to the overall success of an organization and also to determine those issues that are critical to the successful delivery of the specific function or operation concerned. According to [28] performance evaluation categories for a property can be graphically represented as shown in Figure I

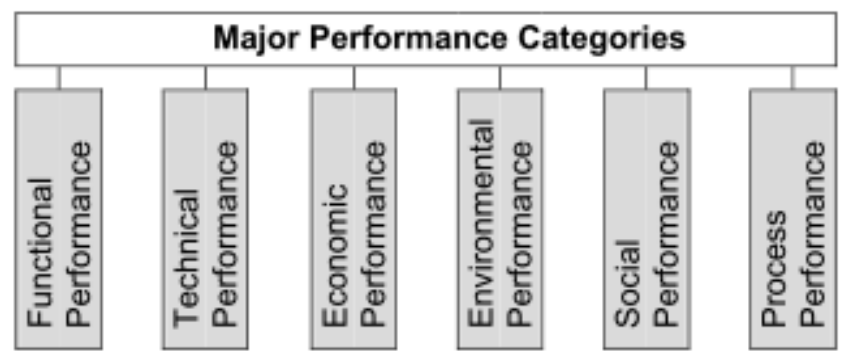

Figure I. Major performance categories Source: Adapted by Durodola et al 2014 from Lutzkendorf et al. (2005).

Most firms only consider how property decisions can improve profitability through space efficiency, cost reduction and capital minimization. Performance measures at times focus on cost per square metre and space per employee. However, real estate decisions contribute to increased revenues as well. Measuring the value of corporate real estate decisions is much more difficult than calculating the financial return on traditional "investment" real estate. Corporate real estate outputs are usually internal outputs to another part of an overall process.

In addition, differently structured and focused firms want different results from their real estate assets, so there is no one indicator of "good" performance by real estate. Rather, the firm should develop a performance measurement system of valid and reliable measures that match their objectives and are reasonable considering available data and resources. Corporate real estate industries believe property and facilities decisions can create value for the core business in several ways; by providing a pleasant and productive physical workplace and provision of responsive and high quality property services to the internal customers. However, there can be a link between the real estate and overall business strategy or no link at all.

\section{Literature Review}

The survey of literature on property performance generally interchanges the use of the following; Improved working environment, Reduced building operating costs, Reduced facilities maintenance costs, Greater capital cost, Lower operating expenditure, Greater demand for space, Lower operating and/or capital expenditure, lower initial return on capital, higher rents, less vacancies, Increases net income or decreases capital, positive impact on value/negative impact on value. All these and others are the major characteristics of an operational nature with particular reference to the utility of the building adopted for measurement of performance of industrial property.

[21] examines the performance of the Nigerian manufacturing sector since independence in 1960 to 1983 , using such performance indices as percentage contribution to the Gross Domestic Product, index of manufactured products, percentage growth rate, manufacturing value added, employment growth rate and percentage of capacity utilization within this period. Secondary sources like the Central Bank of Nigeria Statistical Bulletin, Annual Reports and Statements of Accounts as well as the Statistical Facts sheets of the National Bureau of Statistics and other publications were used in collecting the data. The findings indicate that the Nigerian manufacturing sector has average growth rate of $8.4 \%$ between 2001-2005 while average contribution to the gross domestic product for the period is $5.5 \%$, but the contribution of industrial real estate was not included in the findings.

[29] used panel data analysis on secondary data that was extracted from CBN Statistical Bulletin from 1980-2008 to examine the growth rate and contribution of manufacturing to GDP and found out that positive relationship exist in manufacturing performance for sustainable economic development in Nigeria, between manufacturing and each of capacity utilization and import as 1 percent change in capacity utilization and import lead to 43081 and 3.8 percent change in manufacturing respectively.

[19] examined the relationship between foreign direct investment and the value added to the manufacturing industry in Nigeria between 1970 and 2009. In view of the development and industrializing desires of Nigeria, as well as the foreign aid received in form of private investments, it is pertinent to examine the effect the presence of multinationals has had in shaping the Nigerian manufacturing industry. Using the autoregressive lag distribution technique to determine the relationship between foreign direct investment and manufacturing value added, it was discovered that in the long-run, foreign direct investments have had a negative effect on the manufacturing sub-sector in Nigeria, again the work does not extend to know what is the actual contribution of the real estate to manufacturing production and national economy.

In the foreign countries, [30] contributes to a deeper understanding of the organizational variables "responsibility" and "performance" of real estate functions by identifying 
different organizational models concerning both the functions and responsibilities assigned to corporate real estate (CRE) professionals in European and North American companies and the determination of factors influencing the occurrence of these different management models. 74 major European and 38 North American companies from the banking, energy, telecommunication, and transportation and logistics industries were sampled. The research revealed 5 typical models describing the allocation of responsibility of real estate functions within a company and the performance of those identified responsibilities and infers that no "best practice" CRE management model exist in a specific situation as often stated, but instead, various promising organizational models seem to exist. Although this work is empirical, but it is limited to the organization management of industry but not on industrial contribution measurement

[31] found out that activity-based office concept of the modern office is set to increase productivity through the stimulation of interaction and communication while retaining employee satisfaction and reducing the accommodation costs in the Netherlands. This study shows that the office concept is not always used as intended, what could result in a loss in productivity, illness and dissatisfaction. People's personal preferences seem to have a bigger effect on the use of certain types of workplaces than some workstation facilities, although ergonomics and IT equipment and systems are expected to be satisfactory everywhere. There is however, a need for sound data on the relationship between office design, its intentions and the actual use after implementation.

[32] identified corporate occupiers among the important interest groups in the real estate business. The whole value network in the real estate sector, consisting of, developers, investors, and service providers depend on the occupier organizations and meeting their needs and preferences. The work further investigate the methods applied by the parties in the real estate sector in identifying and evaluating office occupiers' needs and preferences regarding the physical, virtual, social as well as financial elements of the workplace. The findings present an efficient and relevant evaluation of the applied methods in matrix form and recommendations for the development of the methods are suggested with practical implication of analyzing the occupiers' needs and preferences related to physical, virtual, social, and financial elements of offices which require applicable methods.

[33] provided a comparative analysis of industrial corporations in Ireland and those in the non-industrial sector with respect to their corporate real estate management objectives using a behavioural questionnaire targeted at the top 150 companies operating in Ireland and classified on the basis of number of employees. The findings indicate that significant differences are apparent between companies in the industrial sector and companies not in the industrial sector in the use of real estate assets. In particular companies in the industrial/manufacturing sectors have weakly developed corporate real estate strategies. The main limitation of this study is its relatively small sample size, a function of targeting the survey at senior executives. Under-utilization of real estate assets was noted by the work which calls for further investigation on the effects of this on corporate balance-sheets. The work highlights that companies in Ireland, notably those in the industrial sector, have some significant way to go in utilizing their corporate real estate assets more effectively.

26 corporate real estate executives in several countries were interviewed by [34] to present how real estate strategies can add value to the core business, providing real estate managers a tool to illustrate how real estate functions and add value to the corporations. This is with the view to examine the approaches for developing real estate strategies, to measure performance and inquire how real estate adds value to the company and how to measure the value. The work was only able to indicate the contribution of corporate real estate to the core business and that wealth maximization can be modeled to illustrate the effects of real estate to financial performance. Like other previous works, the industrial real estate actual contribution to national economy was however not captured by this work.

\section{The Study Area and Methodology}

Ogun State in South-western Nigeria borders Lagos State to the South, Oyo and Osun states to the North, Ondo State to the east and the republic of Benin to the west. Abeokuta is the capital and largest city in the state. Other notable cities and towns in Ogun State are Ijebu Ode, Sagamu, Ijebu Igbo, Ilaro, Ayetoro and Ota. This study is specifically set in Ota Township, Ogun State, Nigeria. Ota is a peripheral settlement adjoining the Lagos metropolis, located on latitude 6o 42' $\mathrm{N}$ and longitude $6013^{\prime} \mathrm{E}$. In area distance, Ota is about $53 \mathrm{~km}$ to Abeokuta - the Ogun State capital, and $22 \mathrm{~km}$ to Ikeja-the Lagos State capital. Ota is a fast growing medium size industrial town whose physical growth is mainly driven by proximity to two major highways: the Lagos - Abeokuta Expressway and Idiroko Road. These two roads intersect at Sango, the commercial node [35]. Ota is undoubtedly bulkily dominated by manufacturing and industrial establishments.

This work did not measure the value (capital or rental) to determine performance of industrial properties; rather it rated the performance of each standard economic factors of production (land, labour, capital and entrepreneur) base on their contribution to the production activities of the industries. It is an attempt to convert the qualitative perception of the respondents to quantitative measurement. The work adopted the use of questionnaire to elicit the required data for the study. Survey research design was adopted by administering questionnaire through the cross sectional survey.

The questionnaire was semi-structured questions to test the view of the respondents. The study population was the identified head of administration of each industries sampled. Out of 108 industries located in Ota (Ogun State Ministry of Commerce and industries, 2013) 40\% representing 44 industries were randomly sampled to elicit data such as: name of the industries, location, production classification, ownership structure, stock of built assets, average age of assets, usage structure, nature of usage, measurement of utility between 
2008 and 2012, derived in relation to the goal of the establishment among others. To eliminate bias and allow the respondents to have equal chance of being selected random sampling technique was adopted with the use of table of random numbers to select the sample size.

The instrument used for data collection was content validated and Cronbach Alpha Technique index was used for reliability test which gave a value of 0.90 . This technique was pre-tested on a sample of the head of administration of those industries. After collection of data however, appropriate statistical tools were used to analyse the data which meet the scope and nature of data and still were able to answer the research questions.

The data were however collected on the randomly selected industries to represent the whole industries in the study area. Information gathered from the administration of the questionnaires in the study areas were analyzed using both descriptive and inferential statistics. Also, survey of literature on the subject matter was fully explored through journals, textbooks and internet.

\section{Findings and Its Discussion}

This work as earlier indicated does not measure the value (capital or rental) to determine performance of industrial properties; rather it rates the performance of each standard economic factors of production (land, labour, capital and entrepreneur) base on their contribution to the production activities of the industries as perceived by the respondents. The survey findings in table I indicates that 26 of the industries representing (59\%) were owned by Nigerians, 12 representing $(27 \%)$ were owned by foreigners while 6 representing $(14 \%)$ were jointly owned by Nigerians and Foreigners.

Table I. Ownership structure of industrial property.

\begin{tabular}{lll}
\hline Ownership Structure & Frequency & Percentage (\%) \\
\hline Nigerians Only & 26 & 59 \\
Foreigners Only & 12 & 27 \\
Combination of Nigerians And Foreigners & 06 & 14 \\
\hline
\end{tabular}

Source; Authors' Field work (2013)

Only 4 representing (9\%) of the industries have staff housing in addition to administrative, manufacturing and storage housing, 8 representing $18 \%$ use the property for administrative block and storage while 24 representing 55\% use the property for manufacturing purpose as indicated in table II

Table II. Use of industrial property.

\begin{tabular}{lll}
\hline Use of industrial Real Estate & Frequency & Percentage (\%) \\
\hline Administrative block & 08 & 18 \\
Manufacturing & 24 & 55 \\
Storage & 08 & 18 \\
Staff Housing & 04 & 09 \\
\hline
\end{tabular}

Source; Authors' Field work (2013)

Also table III shows that 38 representing (87\%) of the industrial properties were built more than 6 years ago, only 6 representing (13\%) were built 1-10 years ago indicating decline in construction of industry during the period of study.

Table III. Age of industrial property.

\begin{tabular}{lll}
\hline Age Range & Frequency & Percentage $(\%)$ \\
\hline 1-5 years & 02 & 04 \\
6-10 years & 04 & 09 \\
11-15 years & 14 & 32 \\
16-20 years & 18 & 41 \\
21 years above & 06 & 14 \\
\hline
\end{tabular}

Source; Authors' Field work (2013)

Generally, the state of the properties was good as indicated by $55 \%$ responses from the respondents, $14 \%$ of the respondents are of the view that the state of their industrial property was fair, $4 \%$ of the respondents were of the view that the state of repair is poor as indicated in table IV.

Table IV. Condition of industrial property.

\begin{tabular}{lll}
\hline $\begin{array}{l}\text { Condition of industrial } \\
\text { property }\end{array}$ & Frequency & Percentage (\%) \\
\hline Very poor & 00 & 00 \\
Poor & 02 & 04 \\
Fair & 06 & 14 \\
Good & 24 & 55 \\
Very Good & 12 & 27 \\
\hline
\end{tabular}

Source; Authors' Field work (2013)

The responses from the nature of usage of industrial property indicated in table $\mathrm{V}$ that 42 representing (96\%) was owner's occupied, hence no evidence of rent passing on them, while $2(4 \%)$ respondent was of the view that the property was shared in usage with other occupier as tenant. Tables I-V display the attributes of Nigerian manufacturing/industrial industry and graphically presented in figure II

Table $\boldsymbol{V}$. Use nature of industrial property.

\begin{tabular}{lll}
\hline Nature of Use & Frequency & Percentage (\%) \\
\hline Whole usage & 42 & 96 \\
Share Usage & 02 & 04 \\
\hline
\end{tabular}

Source; Authors' Field work (2013)

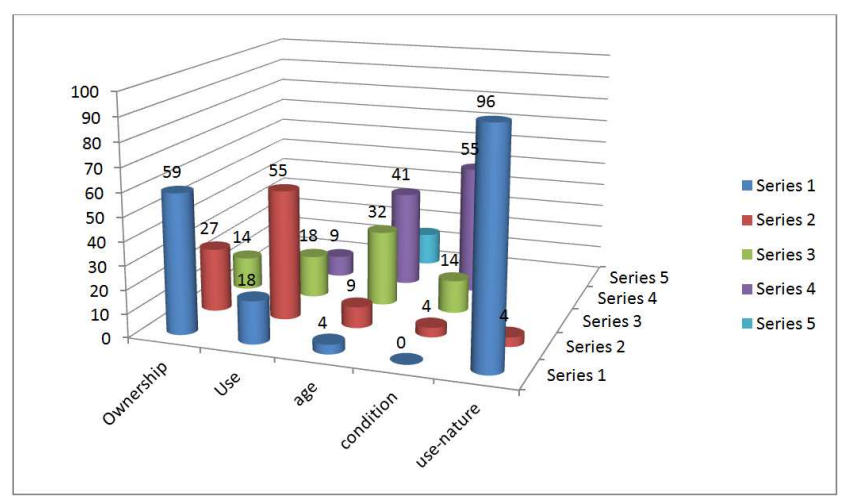

Figure II. Attributes of Manufacturing industry in Nigeria.

Table VI indicated that land contribution to industrial process is $20 \%$, labour $45 \%$, capital $15 \%$ and entrepreneur $20 \%$ 
in 2008 ; in $2009,15 \%, 47 \%, 12 \%$ and $26 \%$ are the contributions of land, labour, capital and entrepreneur respectively; $24 \%, 43 \%, 17 \%$ and $16 \%$ was responded as contribution of land, labour, capital and entrepreneur in 2010. In $2011,17 \%, 38.5 \%, 16.5 \%$ and $28 \%$ are for land, labour capital and entrepreneur respectively while land contribution in 2012 is $19 \%$, labour $31 \%$, capital $19 \%$ and $31 \%$ for entrepreneur. This is represented in figure III. Furthermore, industrial property average contribution for the years 20082012 shows that labour has the highest performance rate of $40.9 \%$ followed by entrepreneur which has $24.2 \%$, then land which has $19 \%$ while capital has the least $15.9 \%$ of the overall participation measurement of industrial performance in Ota, Nigeria. This is presented in figure IV.

Table VI. Distribution of Industrial Income Base on Factors Participation.

\begin{tabular}{lllllll}
\hline The Factors & $\mathbf{2 0 0 8}$ & $\mathbf{2 0 0 9}$ & $\mathbf{2 0 1 0}$ & $\mathbf{2 0 1 1}$ & $\mathbf{2 0 1 2}$ & Average Contribution \\
\hline Land & 20 & 15 & 24 & 17 & 19 & 19 \\
Labour & 45 & 47 & 43 & 38.5 & 31 & 40.9 \\
Capital & 15 & 12 & 17 & 16.5 & 19 & 15.9 \\
Entrepreneur & 20 & 26 & 16 & 28 & 31 & 24.2 \\
\hline
\end{tabular}

Source: Authors' Field Work (2013)



Figure III. Yearly Contribution of factors in production to manufacturing process in Nigeria (2008-2012).

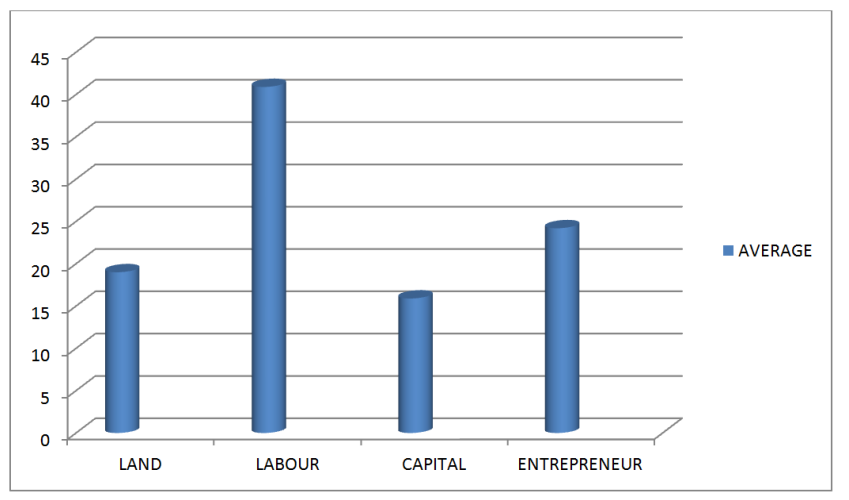

Figure IV. Average Contribution of factors in production to manufacturing process in Nigeria (2008-2012).

Although in yearly analysis 2010 had the highest performance percentage of 24, 2009 had the least performance percentage of 15. Year 2008, 2011 and 2012 have 20\% 17\% and $19 \%$ respectively. In terms of meeting the objectives of having industrial properties, the survey established that the industrial properties have strong responses in term of ability to fulfill the workplace need of business growth and meeting the industrial needs, but the responses was weak as regards ability of the industrial properties to maximize the investment/capital value of the portfolio. It is broadly agreed that rating systems are a powerful driver of sustainable built asset performance. There is very useful research emerging detailing the costs and financial benefits of improving the sustainability of buildings. In fact the standard economic factors of production were used as benchmark of measurement, and data collected were not made to seem implicative as regard possible taxation or other government financial policies. The findings of this survey indicated that industrial properties in Ota contributed $19 \%$ performance to the manufacturing success of industrial establishments, though this contribution is lower than that of labour (40.9\%) and entrepreneur (24.2\%), but it is higher than that of capital $(15.9 \%)$. This indicates that between year 2008 and 2012, at aggregate performance, the industrial properties is relevant to the overall industrial activities in Ota. However, this performance does not have a specific trend (upward or downward), rather it fluctuates during the years of consideration. However, the average of the contribution of manufacturing/industrial sector to Nigerian economy from 2008-2012 as gathered from Central Bank of Nigeria, National Bureau of Statistics, [36] and [37] indicated $3.41 \%$ as presented in table VII and figure V. Also the contribution of manufacturing sector to the national economy just like that of the contribution of industrial real estate to manufacturing output is not steady or specific in trend as shown in figure VI. The implication of this is that while the average contribution of manufacturing sector to national economy during period of study is put at $3.41 \%$, the industrial real estate's actual contribution to Nigerian economy is $0.65 \%$ (19\% of 3.41$)$

Table VII. Manufacturing/Industrial sector share in the Nigerian Gross Domestic Products (2008-2012).

\begin{tabular}{ll}
\hline Year of Consideration & $\begin{array}{l}\text { Percentage Contribution of Manufacturing } \\
\text { sector to GDP }\end{array}$ \\
\hline 2008 & 2.70 \\
2009 & 4.13 \\
2010 & 4.14 \\
2011 & 3.00 \\
2012 & 3.10 \\
Average & 3.41 \\
\hline
\end{tabular}

Source: Central Bank of Nigeria (2013); National Bureau of Statistics (2013), [38] Manufacturing Association of Nigeria (2014) and [39] Nigerian Society of Chemical Engineers (2013).

Table VIII. Combined Contribution of Industrial Real Estate and Industrial sector (2008-2012).

\begin{tabular}{lll}
\hline Year of Consideration & Industrial Real Estate & Industrial Sector \\
\hline 2008 & 20 & 2.70 \\
2009 & 15 & 4.13 \\
2010 & 24 & 4.14 \\
2011 & 17 & 3.00 \\
2012 & 19 & 3.10 \\
Average & 19 & 3.41 \\
\hline
\end{tabular}

Source: Authors Field Work and Combined Secondary sources (2013) 


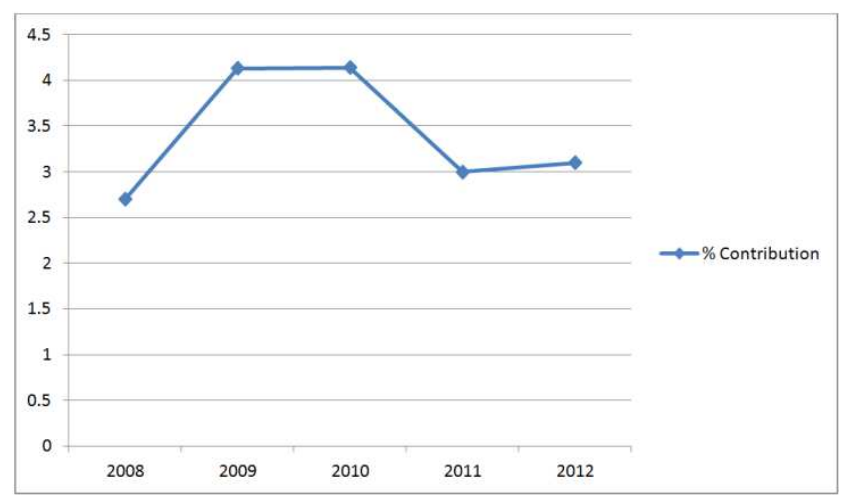

Figure V. Contribution of Industrial/Manufacturing sector to Nigerian GDP (2008-2012).



Figure VI. Combined Contributions of Real Estate and Industrial Sector (2008-2012).

However, much more research needs to be undertaken to help determine the market implications of these innovations, and particularly the economic implications of efforts to satisfy the benchmarks like those advanced in this paper. It is only when it can be emphatically and empirically demonstrated to property investors and managers that such efforts are not just affordable but have significant performance benefits and actually contribute to higher returns performance and premium values that the utility measurement of industrial properties will have meaning and become an integral part of the evaluation approach for industrial investment buildings and be connected to the national economy.

\section{Conclusions}

The significant part of assessing functionality performance of built assets at general term involved determining the measure of achievable sustainability relative to the market. Technological advancement has the potential to produce high sustainability outcomes for buildings, but the cost of much of this innovation is difficult to justify to 'rational economic' investors.

In the case of industrial buildings, stakeholders not only include owners, managers and occupants, but the wider public and government also have a stake in their operation. By this it is meant that management decisions need to be informed by society norms, habits and values, as well as by economic and utility objectives of the parties which this work has attempted to address. In particular there has been keen interest from property investors and managers on the benchmarks for industrial property evaluation.

This work has attempted to advance the benchmarks required for the performance evaluation of industrial buildings without resorting to determination of actual value. Moreover, the benchmarks developed in this work were found to be measurable and appropriate for owner occupied industrial buildings and to make researchers collection of data simple.

The finding of this work supports the claim that the sooner the owner of industrial built asset are able to measure the contribution of their built asset to the overall aim of the establishment and the national economy as a whole, the best will be for them in the sectional appraisal of the contributors to the achievement of the establishment goals and a need to improve and update appropriately. This outcome is also going to be useful for government to fix industrial real estate in the national economic importance as against the usual real estate investment contribution to the national economy.

\section{References}

[1] S.Tsolacos, T. Mcgough \& B. Thompson "Affordability and performance in industrial property market" Journal of property investment \& finance vol. 23 No 4 p 311-328 (2005)

[2] National Bureau of Statistics NBS 'Nigerian Real Estate Sector, Summary Report 2010- 2012' 2015 Real Estate outlook in Nigeria February 2015.

[3] A. Krystalogianni, G. Matysiak, \& S. Tsolacos, "Forecasting UK Commercial Real Estate Cycle Phases With Leading Indicators: A Probit Approach" in Applied Economics (2004)

[4] Y.A. Adewunmi, \& M.M. Ominrin, "Locational choice and business performance in Nigeria" The Estate Surveyor and Valuer Journal of NIESV vol. 32 No. 1 January. (2009)

[5] Y. Zhao 'Industrial property performance and building functionality' an M Sc. In real estate development thesis submitted to the department of architecture, Massachusetts Institute of Technology (2003)

[6] A. Olaleye, 'A study of property portfolio management practice in Nigeria', an unpublished M.sc. Thesis of the department of estate management, Obafemi Awolowo University, Ile-Ife, Nigeria (2000)

[7] Olaleye, A, Adegoke, O.J. and Oyewole, M.O. (2010) 'A Comparative Analysis of the Investment Features of Real Estate and Stocks in Nigeria' Readers Journal 2 (1): 47-65

[8] O.M. Bello, 'Comparative Analysis of the Performance of Residential Property Investment and Investment in Securities in Lagos Nigeria' Journal of Nigerian Institution of Estate Surveyors and Valuers 26 (4):7-14. (2003).

[9] O.M. Bello, 'The Inflation Hedging Characteristics of Nigerian Residential Property Investment' Journal of Property Research and Construction.1 (1):40-55. (2004). 
[10] O.B.A. Idowu, 'Analysis of Residential Property returns in Lagos metropolis (1991- 2004) Environlink - Journal of Physical and Environmental Development 1 (1):166-176 (2006)

[11] M.O. Oyewole, 'A Comparative Study of the Performance of Direct and Indirect Property Investment in Lagos', an unpublished M.Sc. thesis of the Department of Estate Management, Obafemi Awolowo University, Ile-Ife. (2006).

[12] A. Amidu, \& B.T. Aluko, 'Performance analysis of listed construction and real Estate Companies in Nigeria' Journal of Real Estate Portfolio Management 12 (2):177- 185 (2006)

[13] D.I. Dabara, 'Inflation hedging potential of commercial real estate investments in selected state capitals of South-western Nigeria' being an M Sc thesis submitted to Department of Estate Management, Faculty of Environmental Design and Management, Obafemi Awolowo University, Ile-Ife, Nigeria. (2014)

[14] M.O. Ajibola, S.A. Oloyede, \& A.O.E. Oni'Real Estate Investment Trust: An Attractive Investment Vehicle for Real Estate Development in Nigeria' Journal of The Nigerian Institution of Estate Surveyors and Valuers 32 (1):60-66 (2009)

[15] B. Tijjani, S.M.G.Fifield \& D.M. Power The appraisal of equity investments by Nigerian investors. Journal of Qualitative research in financial markets. 1 (1):6-26 (2009).

[16] N.A. Bello 'Comparative Analysis of Commercial Property and Stock-market Investments in Nigeria' World Academy of Science, Engineering and Technology WASET Issue 70 Lucerne October. www.waset.org \& International Journal of Social, Management Economics and Business Engineering vol;6 No 10 (2012)

[17] M.A.Green, "A standard method of property performance measurement; investment analysts” Journal-Spring (1991)

[18] The National Bureau of Statistics (2013)

[19] A.V. Adejumo, "Foreign Direct Investments and Manufacturing Sector Performance In Nigeria, (1970-2009)" Australian Journal of Business and Management Research Vol.3 No.04 [39-56] | July-2013

[20] C. Rajnesh "Industrialization and Development in the third world”. Routledge, London. (1992).

[21] S.A. Banjoko, I.I.Iwuji,\& K. Bagshaw, "The Performance of the Nigerian manufacturing Sector: A 52-Year Analysis of Growth and Retrogression (1960-2012)" Journal of Asian Business Strategy, Vol. 2, No. 8, pp. 177 -191. (2012)

[22] M.O. Kayode, "Nigeria since independence: The first 25 years". Ibadan, Nigeria: Heinemann Books Ltd. (1989)

[23] UNIDO "Changing patterns industrial performance: A UNIDO competitive industrial performance perspective implications for industrial development" Working Paper 05/ 2009, UNIDO, Research and Statistics Branch. (2009)

[24] Torto Wheaton Research modeling the industrial market in United State of America, (2002)

[25] R.S. Kaplan, \& D.P. Norton "Using the Balanced Scorecard as a Strategic Management System", Harvard Business Review, January-February, 75-85. (1996)
[26] R.S. Kaplan, \& D.P. Norton, "Having Trouble with Your Strategy? Then Map It", Harvard Business Review, September-October, 167-76. (2000)

[27] R.S. Kaplan, \& D.P. Norton, "Strategy Maps: Converting Intangible Assets into Tangible Outcomes", Boston: Harvard Business School Publishing Corporation. (2004)

[28] C.M. Burns, "Analysing the Contribution of Corporate Real Estate to the Strategic Competitive Advantage of Organizations" Occupier.org, working papers, available at: http://www.occupier.org/papers/working_paper10.pdf (2002)

[29] A. Lindholm \& S. Nenonem, "A conceptual framework of CREM performance Measurement tools". Journal of Corporate Real Estate. 8 (3):108 - 119. (2006)

[30] T. Lützkendorf, T. Speer, F. Szigeti,G. Davis, P. Le Roux, A. Kato,\& K. Tsunekawa, "A comparison of international classifications for performance requirements and building performance categories used in evaluation methods". Technical Research Centre of Finland (VTT) / Association of Finnish Civil Engineers (RIL). Assessed from http://www.irbnet.de/daten/iconda/CIB6731.pdf (2005)

[31] Olorunfemi, S., Tomola, M. O., Felix, O. A. and Ogunleye E.O. (2013) "Manufacturing Performance In Nigeria: Implication For Sustainable Development" 'Asian Economic and Financial Review, 2013, 3(9):1195-1213

[32] S. Hartmann, P. Linneman, A. Pfnür, D. Moy \& B. Siperstein, "Responsibility for and performance of corporate real estate functions", Journal of Corporate Real Estate, Vol. 12 Iss: 1, pp.7 - 25 (2010)

[33] R. Appel-Meulenbroek, P. Groenen, \& I. Janssen, "An enduser's Perspective on activity-base office concepts", Journal of Corporate Real Estate,Vol. 13 Iss: 2, pp.122 - 135 (2011)

[34] J. Niemi, \& A. Lindholm, "Methods for evaluating office occupiers' needs and preferences" Journal of Corporate Real Estate, Vol. 12 Iss: 1, pp.33 - 46 (2010)

[35] S. Roulac, A. Adair, S. McGreal, J. Berry, L. Brown \& George Heaney, "Corporate strategic decision making: A comparative analysis of companies in the industrial and non- industrial sectors", Journal of Property Investment \& Finance Vol. 23 Iss: 4, pp.364 - 378 (2005)

[36] A. Lindholm, K.M. Gibler, \& K.I. Levainen "Modelling the value adding attributes of real estate to the wealth maximization of the firm", Journal of Real Estate Research, Forthcoming (2006)

[37] T. Salau, T. Lawanson \& O. Yadua 'Amoebic urbanization: the Lagos-Ota nexus in: Laryea, S. and Agyepong, S. (Eds) Procs 5th West Africa Built Environment Research (WABER) Conference, 12-14 August 2013, Accra, Ghana, 99-110. (2013)

[38] Manufacturing Association of Nigeria (MAN) 2014

[39] Nigerian Society of Chemical Engineers (2013) 'Assessment of the manufacturing sector performance in relation to power infrastructure in Nigeria' available at www.nsche.org.ng/cms/publicatios_cms/uploads/assessment/p df. 